JURNAL ILMIAH KEBIDANAN IMELDA

Vol.7, No.2, September 2021, pp.59-64

ISSN: 2597-7180 (Online), 2442-8116 (Print)

http://jurnal.uimedan.ac.id/index.php/JURNALKEBIDANAN

\title{
TINGKAT PENGETAHUAN IBU TENTANG PEMBERIAN SUSU FORMULA PADA BAYI USIA 0-6 BULAN DILINGKUNGAN IX KELURAHAN BANDAR SELAMAT KECAMATAN MEDAN TEMBUNG
}

\author{
Elvalini Warnelis Sinaga
}

Universitas Imelda Medan, Indonesia

\begin{tabular}{l} 
Article Info \\
\hline Article history: \\
Received Sep 03, 2021 \\
Revised Sep 23, 2021 \\
Accepted Sep 28, 2021 \\
\hline
\end{tabular}

Keywords:

Knowledge

Formula Milk

Mother

\begin{abstract}
Formula milk is milk made from real cow's milk or artificial milk by changing its composition which can be used as a substitute for breast milk. Formula milk can be used as a substitute for breast milk or can also be complementary to breast milk. But it must be remembered that none of the nutritional compositions can resemble breast milk. This study aims to better understand and know the advantages and disadvantages of giving formula milk to babies. This research is descriptive in nature using primary data by dividing the questionnaire and tabulating it to get the results. The population of this study were all mothers in Neighborhood IX Bandar Selamat Subdistrict, Medan Tembung District with a total population of 30 respondents and using the total sampling technique as many as 30 respondents. Have less knowledge in junior high school as many as 8 respondents $(27 \%)$, based on the type of work the majority have less knowledge on housewives as many as 11 respondents (37\%), and based on information sources the majority have less knowledge of getting information and electronic media as many as 8 respondents $(26 \%)$. Based on the results of this study, it can be concluded that the mother's level of knowledge regarding formula feeding at the age of $0-6$ months is in the poor category. Therefore, knowledge greatly influences mothers to achieve the Exclusive Breastfeeding program. Therefore, it is hoped that mothers can increase their knowledge about the advantages and disadvantages of formula feeding.
\end{abstract}

This is an open access article under the CC BY-SAlicense.

\section{Corresponding Author:}

Elvalini Warnelis Sinaga,

Program Studi Kebidanan,

Universitas Imelda Medan,

Jl. Bilal No. 52 Kelurahan Pulo Brayan Darat I Kecamatan Medan Timur, Medan - Sumatera Utara.

Email: geoffreygopaz@gmail.com

\section{INTRODUCTION}

Pada masa modern seperti saat ini, sebagian ibu muda merasa enggan menyusui anak. Sebenarnya, gejala tersebut sudah membudaya sekian lama, tidak hanya terjadi di negara-negara maju tetapi juga di negara berkembang, misalnya Indonesia. Kemajuan teknologi serta semakin modernnya komunikasi dan gencarnya promosi susu formula untuk menggantikan fungsi ASI, membuat masyarakat kurang yakin akan kehebatan ASI, sehingga pada akhirnya banyak memilih menggunakan susu formula (Prasetyono, 2009). 
Susu formula digunakan pengganti Air Susu Ibu dan dapat juga pelengkap ASI. Tetapi perlu diingat tidak ada satu pun komposisi zat gizi pada susu formula yang bisa menyamai ASI. Pada saat memilih susu formula harap diperhatikan kandungan gizi yang ada pada susu sebelum membelinya, terutama untuk produk bayi dan anak (Prasetyono, 2009).

Pemberian susu formula terhadap bayi baru lahir yang kurang dari 21 bulan, bisa berbahaya bagi perkembangan anak dan juga bagi orang tuanya. Hasil penelitian yang dilakukan WHO mengenai kesehatan bayi yang terdapat diberbagai negara ternyata menunjukkan hasil bahwa ASI merupakan makanan dengan sumber asupan terlengkap pada bayi baru lahir. Bayi baru lahir yang diberikan ASI eksklusif yaitu tanpa memberikan asupan tambahan lain seperti susu formula akan memiliki pertumbuhan yang sangat baik serta lebih memiliki kekebalan terhadap penyakit. Dan kondisi kegemukan dari anak yang mengkonsumsi susu formula jauh berbeda dibandingkan dengan yang mengkonsumsi ASI saja. Kecerdasandan daya tubuh anak yang mengkonsumsi Air Susu Ibu terhadap penyakit jauh lebih baik dan hal itu sudah dibuktikan oleh penelitian para pakar di dunia (Ronald, 2011).

Hasil penelitian empat dosen Institut Pertanian Bogor (IPB) mengenai susu formula serta makanan bayi yang mengandung bakteri cronobacter sakazakii memang telah menyita perhatian banyak orang. Penelitian yang dilakukan empat dosen IPB tersebut mengungkapkan sebanyak 22,73\% susu formula (dari 22 sampel) dan 40\% makanan bayi (dari 15 sampel) yang di pasarkan April-Juni 2006 telah terkontaminasi bakteri cronobacter sakazakii. Bakteri ini diuji cobakan ke hewan mencit (tikus) ternyata mengalami gangguan otak, usus dan limpa (http://www.forums.apa kabar.Viewtopic).

Sebagian besar susu formula berbahan dasar susu sapi. Dengan kata lain, mengandung protein hewani sebagai sumber nutrisi. Sedangkan formula yang berbahan dasar kedelai lebih kecil kemungkinan menyebabkan alergi pada bayi dibandingkan susu sapi. Namun, ada juga yang alergi terhadap keduanya. Sehingga formula kedelai bisa menjuruskan ke alergi kedelai di masa depan (Warner, 2009).

Salah satu bahan yang hampir selalu tercantum dalam label komposisi susu formula bayi adalah Docosahexaehoic Acid atau lebih dikenal dengan DHA. Zat ini memiliki fungsi mengembangkan kecerdasan bayi. Gencarnya tayangan iklan susu formula yang mengandung DHA secara langsung membesarkan zat yang satu ini. Namun DHA bukanlah zat yang sempurna (Prasetyono, 2009).

Dr. Widodo Judarwanto SpA, mengatakan bahwasanyaESPGAN (European Society for Pediatric Gastroenterology and Nutrition), British Nutrition Foundation merekomendasikan penambahan komposisi AA \& DHA untuk susu formula yang ditujukan pada bayi prematur. Rekomendasi ini cukup beralasan karena penelitian pemberian asupan DHA untuk bayi prematur dapat meningkatkan perkembangan sistem syaraf bayi tersebut (http://www.susuformula.com).

Berdasarkan hasil survei Demografi Kesehatan Indonesia (pada tahun 1997-2003) didapatkan hasil bahwa jumlah pemberian ASI menurun mulai dari 49\% sampai 39\%, namun pemberian susu formula meningkat menjadi tiga kali lipat. Informasi itu disampaikan oleh Ketua Badan Kerja Peningkatan Penggunaan Air Susu Ibu (BKPP-ASI), dr. Dien Sanyoto Besar, Sp.A (Prasetyono, 2009).

Menurut hasil penelitian yang didapatkan Muhammad Enoch dan Djumadias Abunaim di Jakarta, angka kejadian diare yang dialami bayi yang diberi ASI hanya 6\%, diberi ASI dan susu formula hanya 14\%, dan jika diberi susu formula saja angka kejadian diare meningkat menjadi $18 \%$. Susu fomula boleh jadi berperan sebagai wahana pembiakan bakteri patogen enterik atau produksi enterotoksin (Arisman, 2009).

Penambahan prebiotik atau simbiotik untuk memperbaiki saluran cerna bukanlah yang utama. Apabila bahan dasar pengolahan susu formula bisa diterima oleh saluran pencernaan, maka tambahan kandungan dirasa tidak terlalu bermanfaat. Namun bila terjadi gangguan pencernaan yang berkepanjangan maka yang terpenting adalah mencari pilihan susu yang tidak menimbulkan masalah pada saluran pencernaan.

Berdasarkan survey awal yang dilakukan oleh peneliti terdapat data dari posyandu yang menunjukkan peningkatan penggunaan susu formula sebanyak 12\% dari tahun 2019-2020. Dari uraian diatas maka penulis melakukan penelitian di Lingkungan IX Kelurahan Bandar Selamat Kecamatan Medan Tembung karena jumlah ibu-ibu yang memberikan susu formula kepada bayinya yang berusia 0-6 bulan masih sangat tinggi. Untuk itu penulis ingin lebih mengetahui tingkat pemahaman ibu terhadap pemberian susu formula terhadap bayinya.

\section{RESEARCH METHOD}

Penelitian ini bersifat deskriptif yang menggunakan data primer dengan teknik pengambilan data dengan membagi kuesioner dan ditabulasikan untuk mendapatkan hasil. Populasi yang digunakan ialah seluruh ibu di lingkungan IX Kelurahan Bandar Selamat Kecamatan Medan Tembung dengan jumlah populasi sebanyak 30 responden, yang menggunakan teknik total sampling sebanyak 30 responden dengan ketentuan ibu memiliki bayi usia 0-6 bulan dan memberikan susu formula, adapun yang menjadi kriteria eksklusi adalah ibu yang memberikan ASI Eksklusif. 


\section{RESULTS AND ANALYSIS}

3.1Hasil

Setelah dilakukan penelitian terhadap 30 responden di Lingkungan IX Kelurahan Bandar Selamat Kecamatan Medan Tembung mengenai "Pengetahuan Ibu Terhadap Pemberian Susu Formula Pada Bayi Usia 0-6 Bulan" maka didapatkan hasil sebagai berikut:

\section{a. Pengetahuan Responden}

Tabel 1. Distribusi Frekuensi Pengetahuan Ibu Terhadap Pemberian Susu Formula pada Bayi Usia 0-6 Bulan di Lingkungan IX Kelurahan Bandar Selamat Kecamatan Medan Tembung

\begin{tabular}{cccc}
\hline No & Pengetahuan & Frekuensi & \% \\
\hline 1 & Baik & 3 & 10 \\
\hline 2 & Cukup & 12 & 40 \\
\hline 3 & Kurang & 15 & 50 \\
\hline & Jumlah & $\mathbf{3 0}$ & $\mathbf{1 0 0}$
\end{tabular}

Berdasarkan tabel 1 dijelaskan bahwa pengetahuan ibu dalam pemberian susu formula pada usia 0-6 bulan kebanyakan berpengetahuan kurang dengan 15 responden $(50 \%)$ dan sedikit berpengetahuan baik 3 responden $(10 \%)$.

\section{b. Pendidikan}

Setelah penelitian, distribusi responden berdasarkan pendidikan ialah:

Tabel 2. Distribusi Frekuensi Pengetahuan Ibu Terhadap Pemberian Susu Formula Pada Bayi Usia 0-6 Bulan

Berdasarkan Pendidikan di Lingkungan IX Kelurahan Bandar Selamat Kecamatan Medan Tembung

\begin{tabular}{cccccccccc}
\hline & & \multicolumn{9}{c}{ Pengetahuan } & \multicolumn{2}{c}{ Jumlah } \\
\cline { 3 - 8 } No Pendidikan & \multicolumn{2}{c}{ Baik } & \multicolumn{2}{c}{ Cukup } & \multicolumn{2}{c}{ Kurang } & & \\
\cline { 3 - 8 } & & F & $\mathbf{\%}$ & F & \% & F & \% & F & \% \\
\hline 1 & SD & - & - & - & - & 4 & 13 & 4 & 13 \\
\hline 2 & SMP & - & - & 3 & 10 & 8 & 27 & 11 & 37 \\
\hline 3 & SMA & 1 & 3 & 7 & 23 & 3 & 10 & 11 & 37 \\
\hline 4 & P. Tinggi & 2 & 7 & 2 & 7 & - & - & 4 & 13 \\
\hline & Jumlah & $\mathbf{3}$ & $\mathbf{1 0}$ & $\mathbf{1 2}$ & $\mathbf{4 0}$ & $\mathbf{1 5}$ & $\mathbf{5 0}$ & $\mathbf{3 0}$ & $\mathbf{1 0 0}$ \\
\hline
\end{tabular}

Dari tabel 2 dapat terlihat bahwa pengetahuan ibu mengenai pemberiean susu formula pada usia 0-6 bulan dari segi pendidikan ibu, kebanyakan responden memiliki pengetahuan kurang karena berlatar belakang SMP sebanyak 8 orang $(27 \%)$ dan sedikit responden berpengetahuan baik untuk SMA sebanyak 1 responden $(3 \%)$.

\section{c. Pekerjaan}

Tingkat Pengetahuan Ibu tentang Pemberian Susu Formula pada Bayi Usia 0-6 Bulan di Lingkungan IX Kelurahan Bandar Selamat Kecamatan Medan Tembung yang berjumlah 30 responden didapatkan hasil distribusi responden menurut data demografi berdasarkan pekerjaan dilihat pada tabel dibawah ini:

Tabel 3. Distribusi Frekuensi Tingkat Pengetahuan Ibu Terhadap Pemberian Susu Formula Pada Bayi Usia 0-6 Bulan Berdasarkan Pekerjaan di Lingkungan IX Kelurahan Bandar Selamat Kecamatan Medan Tembung

\section{Pengetahuan}

\begin{tabular}{cccccccccc}
\multirow{2}{*}{ No } & Pekerjaan & \multicolumn{9}{c}{ Baik } & \multicolumn{9}{c}{ Cukup } & \multicolumn{2}{c}{ Kurang } & \multicolumn{2}{c}{ Jumlah } \\
\cline { 3 - 9 } & & F & $\mathbf{\%}$ & F & \% & F & \% & F & \% \\
\hline 1 & IRT & - & - & 4 & 13 & 11 & 37 & 15 & 50 \\
\hline 2 & PNS & 1 & 3 & - & - & - & - & 1 & 3 \\
\hline 3 & Karyawan & 2 & 7 & 8 & 27 & 4 & 13 & 14 & 47 \\
\hline & Jumlah & $\mathbf{3}$ & $\mathbf{1 0}$ & $\mathbf{1 2}$ & $\mathbf{4 0}$ & $\mathbf{1 5}$ & $\mathbf{5 0}$ & $\mathbf{3 0}$ & $\mathbf{1 0 0}$ \\
\hline
\end{tabular}

Dari tabel 3 dijelaskan pengetahuan ibu terhadap pemberian susu formula pada bayi 0-6 bulan berdasarkan pekerjaan kebanyakan responden memiliki pengetahuan kurang bekerja sebagai IRT sebanyak 11 responden $(37 \%)$ dan minoritas responden memiliki pengetahuan baik yang bekerja sebagai PNS sebanyak 1 responden $(3 \%)$.

\section{d. Sumber Informasi}

Tingkat Pengetahuan Ibu Terhadap Pemberian Susu Formula pada Bayi Usia 0-6 Bulan di Lingkungan IX Kelurahan Bandar Selamat Kecamatan Medan Tembung yang berjumlah 30 responden 
didapatkan hasil distribusi responden menurut data demografi berdasarkan sumber informasi dilihat pada tabel dibawah ini:

Tabel 7. Distribusi Frekuensi Tingkat Pengetahuan Ibu Terhadap Pemberian Susu Formula Pada Bayi Usia 06 Bulan Berdasarkan Sumber Informasi di Lingkungan IX Kelurahan Bandar Selamat Kecamatan Medan Tembung

\begin{tabular}{|c|c|c|c|c|c|c|c|c|}
\hline \multirow{3}{*}{ Sumber Informasi } & \multicolumn{6}{|c|}{ Pengetahuan } & \multirow{2}{*}{\multicolumn{2}{|c|}{ Jumlah }} \\
\hline & \multicolumn{2}{|c|}{ Baik } & \multicolumn{2}{|c|}{ Cukup } & \multicolumn{2}{|c|}{ Kurang } & & \\
\hline & $\mathbf{F}$ & $\%$ & $\mathbf{F}$ & $\%$ & $\mathbf{F}$ & $\%$ & $\mathbf{F}$ & $\%$ \\
\hline Tenaga Kesehatan & 2 & 7 & 2 & 7 & 5 & 17 & 9 & 30 \\
\hline Keluarga & - & - & 4 & 13 & 2 & 7 & 6 & 20 \\
\hline Media Elektronik & 1 & 3 & 6 & 20 & 8 & 26 & 15 & 50 \\
\hline Jumlah & 3 & 10 & 12 & 40 & 15 & 50 & 30 & 50 \\
\hline
\end{tabular}

Dari Tabel 7 dijelaskan bahwa pengetahuan ibu dalam pemberian susu formula pada bayi 0-6 bulan berdasarkan sumber informasi kebanyakan responden berpengetahuan kurang dapatkan informasi dari media mendapat informasi dari media elektronik sebanyak 8 responden $(26 \%)$ dan sedikit responden dengan pengetahuan baik dalam mendapatkan informasi dari media elektronik sebanyak 1 responden (3\%).

\subsection{Pembahasan \\ Pengetahuan Responden}

Hasil penelitian yang telah dilaksanakan pada tabel 4 dapat disimpulkan pengetahuan ibu terhadap pemberian susu formula pada bayi 0-6 bulan kebanyakan kurang sebanyak 15 responden (50\%) dan sedikit pengetahuan baik 3 responden (10\%).

Pengetahuan ibu tentang pemberian susu formula dalam kategori kurang sebanyak 15 responden dari 30 responden, hal tersebut disebabkan oleh kurangnya informasi dan wawasan ibu, sehingga belum mencapai pengetahuan yang baik. Hal yang sesuai dengan yang dikemukanan (Fitriani dan Mubarak, 2011) pengetahuan merupakan hasil tahu, setelah seseorang melakukan pengindraan manusia, yakni dnegan penglihatan, penciuman, pendengaran rasa dan raba. Keinginan untuk memiliki pengetahuan merupakan dorongan setiap manusia tidak hanya mengetahui apa yang terjadi, tetapi juga ingin tahu apa yang terjadi saat ini dan ingin memperkirakan apa yang terjadi dimasa yang akan datang. Pada umumnya pengetahuan akan terus bertambah dan bervariasi dengan proses pengalaman yang dialami.

\section{Tingkat Pengetahuan Ibu Berdasarkan Pendidikan}

Hasil penelitian pada tabel 5 diketahui bahwa pengetahuan ibu terhadap pemberian susu formula pada bayi 0-6 bulan pada pendidikan kebanyakan responden memliki pengetahuan kurang pada dengan latar belakang SMP sebanyak 8 responden (27\%) dan sedikit pengetahuan baik dengan latar belakang SMA sebanyak 1 orang $(3 \%)$. Pendidikan mempunyai peran penting mementukan kualitas manusia, sehingga melalui pendidikan manusia dianggap memperoleh pengetahuan. Dengan pengetahuan yang dimiliki manusia mampu membangun keberadaan hidupnya dengan lebih baik dan mengetahui bagaimana dalam pemberian susu formula pada bayi 0-6 bulan dan mengetahui keuntungan /kerugiannya.

Menurut (Wawan dan Mubarak, 2011) pendidikan ialah bimbingan yang diberikan seseorang ke orang lain yang dapat berkembang menuju ke arah cita-cita tertentu agar dapat untuk berbuat dan mengisi kehidupan dalam mencapai kebahagiaan. Makin tinggi pendidikan, seorang makin mudah menerima informasi, dan pada akhirnya pengetahuan yang dimilikinya akan semakin berkembang.

\section{Tingkat Pengetahuan Ibu Berdasarkan Pekerjaan}

Hasil penelitian pada tabel 6 dijelaskan bahwa pengetahuan ibu dalam pemberian susu pada bayi 0-6 bulan berdasarkan pekerjaan kebanyakan responden pengetahuan kurang tingkat pengetahuan diperoleh dari sebuah pekerjaan karena dari pekerjaan seseorang dapat memperoleh pengetahuan dan hal yang baru yang diperoleh dari tempat dimana dia bekerja. Hal ini sesuai dengan teori (Wawan dan Mubarak, 2011), pekerjaan ialah aktivitas yang dilakukan untuk menunjang kehidupan maupun kehidupan keluarga. Bekerja pada dasarnya kegiatan yang memerlukan watu, lingkungan dapat membuat seseorang mendapat pengalaman dan juga pengetahuan, baik secara langsung atau tidak langsung. Bekerja bagi ibu akan mempunyai pengaruh terhadap kehidupan keluarga.

\section{Tingkat Pengetahuan Ibu Berdasarkan Sumber Informasi}

Hasil penelitian pada tabel 7 diketahui bahwa pengetahuan ibu dalam pemberian susu formula bayi 0-6 bulan berdasarkan sumber informasi kebanyakan memiliki pengetahuan kurang mendapat informasi dari 
elektronik sebanyak 8 responden $(26 \%)$ dan sedikit berpengetahuan baik mendapat informasi dari media elektronik sebanyak 1 orang $(3 \%)$.

Sumber informasi yang tepat didapat dari petugas kesehatan walaupun dengan semakin canggihnya media elektronik memberikan informasi yang luas sehingga meningkatkan pengetahuan yang baik tentang kesehatan. Informasi yang diperoleh dari responden dalam pemberian susu formula yaitu kurangnya dan banyaknya dari media eletronik.

Menurut (Notoatmodjo, 2003), bila seseorang memperoleh informasi maka orang tersebut cenderung memiliki pengetahuan yang lebih luas, informasi yang diperoleh mencakup banyak aspek termasuk diantaranya pemberian susu formula pada bayi usia 0-6 bulan dapat diperoleh dari tenaga kesehatan, majalah, TV, radio dan koran. Dalam hal ini semakin banyak informasi yang diperoleh ibu maka semakin tinggi pemahaman dan pengetahuan pada hal tersebut.

\section{CONCLUSION}

Dari penelitian yang telah peneliti lakukan mengenai Tingkat Pengetahuan Ibu Terhadap Pemberian Susu Formula pada Bayi Usia 0-6 Bulan di Lingkungan IX Kelurahan Bandar Selamat Kecamatan Medan Tembung kesimpulan sebagai berikut:

a. Berdasarkan hasil penelitian dapat diketahui bahwa mayoritas responden berpengetahuan kurang sebanyak 15 responden (50\%) dan minoritas berpengetahuan baik 3 responden (10\%).

b. Berdasarkan hasil penelitian dapat dilihat bahwa berdasarkan pendidikan mayoritas responden berpengetahuan kurang pada SMP sebanyak 8 responden (27\%) dan minoritas responden berpengetahuan baik pada SMA sebanyak 1 responden $(3 \%)$.

c. Berdasarkan hasil penelitian dapat dilihat bahwa berdasarkan pekerjaan mayoritas responden berpengetahuan kurang pada IRT sebanyak 11 responden (37\%) dan minoritas responden berpengetahuan baik pada PNS sebanyak 1 responden (3\%).

d. Berdasarkan hasil penelitian dapat dilihat bahwa berdasarkan sumber informasi mayoritas responden berpengetahuan kurang mendapat informasi dari media elektronik sebanyak 8 responden (26\%) dan minoritas responden berpengetahuan baik mendapat informasi dari media elektronik sebanyak 1 responden $(3 \%)$.

\section{REFERENCES}

Arikunto Suharsimi, 2005. Manajemen Penelitian. Rineka Cipta: Jakarta.

Arikunto Suharsimi. 2006. Prosedur Penelitian Suatu Pendekatan Praktik. Rineka Cipta: Jakarta.

Arisman, 2010.Gizi Dalam Daur Kehidupan. EGC: Jakarta.

Cadwell Karin, dkk., 2011. Buku Saku Manajemen Laktasi. EGC: Jakarta.

FitrianiSinta, 2011. Promosi Kesehatan. Graha Ilmu: Jakarta.

Machfoedz Ircham, 2009. Metode Penelitian. Fitramaya. Yogyakarta.

Mubarak Wahid Iqbal, 2011. Promosi Kesehatan Untuk Kebidanan. Salemba Medika: Jakarta.

NadesulHandrawan, 2007. Membesarkan Bayi Jadi Anak Pintar. Buku Kompas: Jakarta.

Notoatmodjo, Soekidjo, 2003. Pendididikan dan Perilaku Kesehatan. Rineka Cipta: Jakarta.

Notoatmodjo, Soekidjo,2007. Kesehatan Masyarakat.Rineka Cipta: Jakarta.

Notoatmodjo, Soekidjo, 2010. Metodelogi Penelitian. Rineka Cipta: Jakarta.

Petti, 2011. Bakteri Susu Formula.http://www. Forums.apa kabar. View topic.

PrasetyonoDwi Sunar, 2009. Buku Pintar ASI Eksklusif. DIVA Press: Yogyakarta.

ProverawatiAtikah dan Rahmawati, E., 2010. Kapita Selekta ASI \&Menyusui. Nuha Medika: Yogyakarta.

Ronald, 2011. Pedoman \& Perawatan balita Agar Tumbuh Sehat dan Cerdas. CV Nuansa Aulia: Bandung.

Simkin Penny, dkk., 2008. Panduan Lengkap Kehamilan, Melahirkan \& Bayi. Arcan: Jakarta.

Suherni, dkk., 2009. Perawatan Masa Nifas. Fitramaya: Yogyakarta.

Sulistyaningsih, 2011. Metodologi Penelitian Kebidanan. Graha Ilmu: Yogyakarta.

Wawan dan Dewi, 2011. Pengetahuan Sikap dan Prilaku Manusia. Nuha Medika: Yogyakarta

WarnerPenny, 2009. 365 Kiat Mengasuh Bayi. Arcan: Jakarta. 


\section{BIOGRAPHIES OF AUTHORS}

\begin{tabular}{l|l|} 
Elvalini Warnelis Sinaga, Gelar D-III diperoleh dari Akademi Kebidanan Imelda \\
Medan, Jurusan Kebidanan pada tahun 2009. Gelar Sarjana diperoleh dari Poltekes \\
Kemenkes RI Medan, Jurusan Bidan Pendidik Tahun 2011. Magister Kesehatan \\
diperoleh dari Universitas Sumatera Utara, Jurusan Kesehatan Reproduksi pada tahun \\
2018. Saat ini aktif sebagai dosen tetap di Prodi D-III Kebidanan Universitas Imelda \\
Medan dan menjabat sebagai Sekretaris Prodi.
\end{tabular}

